\title{
Large-Scale Transparent Photovoltaics for a Sustainable Energy Future: Review of Inorganic Transparent Photovoltaics
}

\author{
Received 16 December, 2021; accepted 4 January, 2022
}

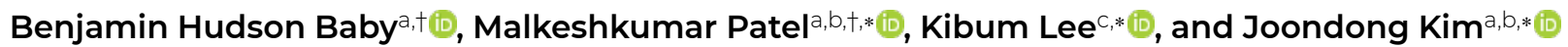 \\ aphotoelectric and Energy Device Application Lab (PEDAL) and Multidisciplinary Core Institute for Future Energies \\ (MCIFE), Incheon National University, Incheon 22012, Republic of Korea \\ bDepartment of Electrical Engineering, Incheon National University, Incheon 22012, Republic of Korea \\ cSolarLight Ltd, 119 Academy Rd., Incheon 22012, Republic of Korea
}

†These authors equally contributed to this work.

*Corresponding author E-mail: mpatel@inu.ac.kr, solarlight_1@naver.com, joonkim@inu.ac.kr

\begin{abstract}
Transparent photovoltaics (TPVs) are a crucial energy platform for harvesting solar energy in windows, enabling onsite power generation for widespread applications in buildings, vehicles, displays, sensors, and the Internet of things. TPV devices are fabricated using eco-friendly processing methods and materials, and must perform stably for an adequate societal impact. This review article is focused on the emerging TPV devices made of inorganic materials, including oxides and two-dimensional sulfides. Herein, we briefly review the wide-bandgap inorganic TPVs and their performances. Specifically, the sputtering method is considered for the large-scale and eco-friendly preparation of inorganic heterostructures.
\end{abstract}

Keywords: Transparent photovoltaic, Inorganic thin film, Onsite power generation, Large-scale fabrication

\section{Introduction}

The two outcomes of the industrial development in the modern era, viz. a high energy demand and global warming, have compelled the technologists to turn to naturally available and environment-friendly sources of renewable energy. Figure 1(a) indicates a growth in global electricity production, using renewable energy sources, from 24.5 (20 $16)$ to $26.3 \%$ (2018) [1]. Among the sources of renewable energy, electricity production from wind and solar energy showed a remarkable increase from 4.0 to $5.5 \%$ and 1.5 to $2.4 \%$, respectively, between 2016 and 2018, indicating the focus that these technologies have received in the recent years. Photovoltaic technology has the capacity to meet the requirements of the future energy demand of humankind with a reduced environmental impact. The amount of energy that the Sun delivers to Earth per hour is approximately equal to the total energy consumption of humanity per year $\left(\sim 5 \times 10^{20} \mathrm{~J}\right.$ in 2018$)$ [2-5]. In the recent years, photovoltaic technology has undergone commendable improvements, resulting in the development of highly efficient, lowcost, and environment-friendly solar cells. These achievements have been realized by modifying both the fabrication processes and materials used. The current renewable energy trends indicate that the renewable electricity production will exceed the energy production from fossil fuels by 2026. Likewise, in 2040, two-thirds of the global electricity supply is expected to be derived from renewable sources. Expectedly, solar and wind power would produce $40 \%$ of the energy used, and the other renewable energy sources, including hydropower and bioenergy, would account for $25 \%$ of the total energy production [1].

At present, $95 \%$ of the photovoltaic device market is controlled by Si-wafer-based solar cells, which are first-generation products. To improve the efficiency-cost ratio, second-generation cells, based on the thin-film technology, have been introduced. Thin-film solar cells made of cadmium telluride, copper indium gallium sulfide, and copper zinc tin sulphur selenide show efficiencies of 22.1, 22.6, and $12.6 \%$, respectively [18-22]. The emerging photovoltaic techniques are included in the third generation of solar cells, mainly perovskite, tandem, dye-sensitized, organic, and quantum-dot solar cells with power conversion efficiencies (PCEs) of 25.2, 29.1, 12.3, 17.4, and 16.6\%, respectively $[18,23,24]$.

However, the large surface area, required for the installation of these opaque photovoltaics, is a hindering factor for the energy requirements of humankind. Thus, transparent photovoltaic (TPV) cells

$$
\text { (a) }
$$

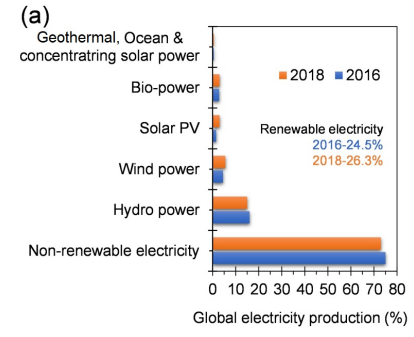

(b)

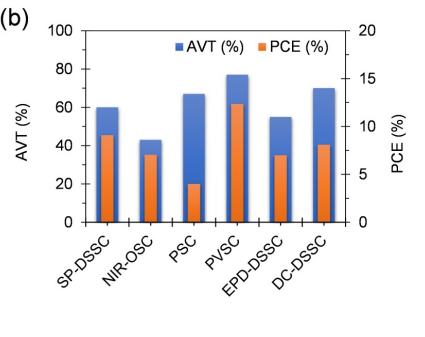

Figure 1. Global energy scenario and TPVs. (a) Comparison of global electricity production, using different sources, for 2016 and 2018 [1]. (b) Highest PCE reported for various TPVs along with their AVT values [6-17]. 
Table I. AVT values and photovoltaic performance of different types of TPV devices, indicating the short-circuit current densities $\left(\mathrm{J}_{\mathrm{sc}}\right)$, open-circuit voltages $\left(\mathrm{V}_{\mathrm{oc}}\right)$, fill factors (FF), efficiencies $(\eta)$, and active areas (A) of the devices.

\begin{tabular}{|c|c|c|c|c|c|c|c|}
\hline TPV & $\begin{array}{c}\text { AVT } \\
(\%)\end{array}$ & $\begin{array}{c}\mathrm{J}_{\mathrm{sc}} \\
\left(\mathrm{mA} / \mathrm{cm}^{2}\right)\end{array}$ & $\begin{array}{c}\mathrm{V}_{\mathrm{oc}} \\
(\mathrm{mV})\end{array}$ & $\begin{array}{l}\text { FF } \\
(\%)\end{array}$ & $\begin{array}{c}\eta \\
(\%)\end{array}$ & $\begin{array}{c}\mathrm{A} \\
\left(\mathrm{mm}^{2}\right)\end{array}$ & Ref. \\
\hline SP-DSSC & 60 & 16.25 & 779 & 73 & 9.2 & - & [7] \\
\hline NIR-OSC & 43 & 15.8 & 680 & 66 & 7.1 & - & {$[10]$} \\
\hline PVSC & 77 & 17.5 & 1025 & 71 & 12.7 & 39 & {$[28]$} \\
\hline EPD-DSSC & 55 & 14.23 & 680 & 71 & 7.1 & 25 & {$[13]$} \\
\hline DC-DSSC & 70 & 16.17 & 738 & 69 & 8.22 & - & {$[14]$} \\
\hline
\end{tabular}

are attracting significant interest in photovoltaic research because of their wide application as building-integrated, building-applied, and vehicle-integrated photovoltaic devices $[25,26]$. Hence, TPV technology could aid in the conversion of the largest energy consumers into the largest power plants. In conventional solar cells, the absorption of visible light leads to the generation of electron-hole pairs that produce current. In contrast, TPVs allow the visible light to pass through and generate current by absorbing ultraviolet (UV) light photons. Therefore, TPV devices meet our high energy demands as well as block the hazardous part of the electromagnetic spectrum. The ShockleyQueisser maximum theoretical efficiency limit for a TPV is $~ 20 \%$, whereas for the conventional photovoltaics (CPVs), this limit is $~ 32 \%$ $[26,27]$. Although the TPVs exhibit low PCEs than do the CPVs, their features like transparency, onsite power production, protection from high-energy photons like UV, and high flexibility paved a new pathway for the widespread application of TPVs.

Table I shows a comparison of the photovoltaic performance of different types of TPVs along with their average visible-light transmittance (AVT) values. Figure 1(b) compares the reported highest PCE and AVT values for different types of TPVs (AVT > 40\%) such as screen-printed dye-sensitized solar cells (SP-DSSC), near-infraredorganic solar cells (NIR-OSC), polymer solar cells (PSCs), perovskite solar cells (PVSC), electrophoretic deposition dye-sensitized solar cells (EPD-DSSC), and dip coated-dye sensitized solar cells (DC-DSSC) $[6,7,10,11,13,14,28,29]$. Among these, the highest PCE, i.e., $12.7 \%$ (AVT of 77\%), is exhibited by the perovskite solar cells with a device configuration of $\mathrm{TiO}_{2} / \mathrm{MAPbI}_{3}$ /spiro-OMeTAD/AgNW (where NW represents nanowire). However, the use of conventional organic spiro-OMeTAD in the device configuration as a hole transport layer hinders its further development owing to the complex synthesis procedure, high cost, and instability. The commercially available spiroOMeTAD is nearly 23 times more expensive than $\mathrm{Au}$ and $\mathrm{Pt}$, by its weight percentage [30]. Hence, although these devices exhibit high PCEs ( $>4 \%)$, their toxicity and high costs, along with the low stability of their organic molecules, are the major limitations of these devices. Consequently, the recent investigations in the field of TPV technology have been focused either on overcoming these hurdles by introducing suitable alternatives or moving toward inorganic TPV technology. Thus, inorganic TPV technology has become more attractive because of the incorporation of wide-band-gap metal oxides as the active UV layer.

Wide-band metal oxides are promising candidates in the search for naturally available and acceptable semiconductor materials, in the field of inorganic TPVs [31-33]. Figure 2 presents a schematic diagram of an inorganic TPV. It consists of top and bottom transparent electrodes, separated by a surface field layer, and wide-band-gap metal oxides with n-type conductivity, such as $\mathrm{ZnO}, \mathrm{TiO}_{2}$, and so forth, and those with p-type conductivity, such as $\mathrm{NiO}, \mathrm{CuAlO}_{2}$, and $\mathrm{Cu}_{2} \mathrm{O}$. The wide band gaps of these materials allow visible-light transmittance and UV-light absorbance, which are the underlying principles of TPV applications. Incident UV photons with energies higher than the band gap of the materials result in the formation of electron-hole pairs. Further, charge separation is achieved using built-in electric fields generated by the $\mathrm{p}-\mathrm{n}$ heterojunction. The separate extraction of these charge carriers to the external circuit results in the generation of electricity. The surface field layer prevents the recombination of the minority carriers.

A literature review indicated that inorganic TPVs have attracted considerable research interest since 2013 because of the improvements in photovoltaic performance, facilitated by the incorporation of various mechanisms, to overcome the factors that limit device efficiency $[15,33-43]$. Over the past few years, several research groups have reviewed the technologies underlying TPVs, semi-transparent thin-film TPVs, and organic TPVs $[6,26,44-46]$. However, no reports are available on inorganic TPVs. Thus, considering the promising aspects of inorganic TPVs, in this review article, we focus on the fabrication and mechanisms of inorganic TPVs, along with the improvements in their performance (AVT $<40 \%)$, which may provide support to the future investigations for attaining commercially acceptable costefficiency ratios. In the TPVs, the $\mathrm{p}-\mathrm{n}$ heterojunction is typically prepared using the reactive sputtering technique, and consequently, this review article highlights the optoelectrical properties of the reactivesputtered wide-band-gap metal-oxide films.

\section{Wide-band-gap metal oxides for inorganic TPVs}

Some widely used wide-band-gap metal oxide materials are $\mathrm{NiO}$, $\mathrm{Cu}_{2} \mathrm{O}$, and $\mathrm{Cu}$ delafossite $\left(\mathrm{CuGaO}_{2}, \mathrm{CuCrO}_{2}, \mathrm{CuFeO}_{2}\right.$, and $\left.\mathrm{CuFeO}_{2}\right)$, which are p-type materials, and $\mathrm{ZnO}, \mathrm{AZO}, \mathrm{TiO}_{2}, \mathrm{SnO}_{2}$, and $\mathrm{Zn}_{2} \mathrm{SnO}_{4}$, which are $n$-type materials. Table II compares the optical and electrical properties of these metal oxides along with their deposition parameters $[37,39,47-59]$. Figure 3 presents an energy-level diagram of both the p-type and n-type metal oxides [33,60-66].

$\mathrm{NiO}$ has a rock salt crystal structure with octahedral $\mathrm{Ni}^{2+}$ and $\mathrm{O}^{2-}$ sites. It exhibits a wide band gap in the range of 3.5-4 eV, allowing a higher transmission of visible light, p-type conductivity, large absorption coefficients $\left(10^{5} \mathrm{~cm}^{-1}\right)$, high stability, and high work function $(\sim 5.0 \mathrm{eV})[30,68]$. Due to its low electron affinity $(1.33-1.85 \mathrm{eV})$, a

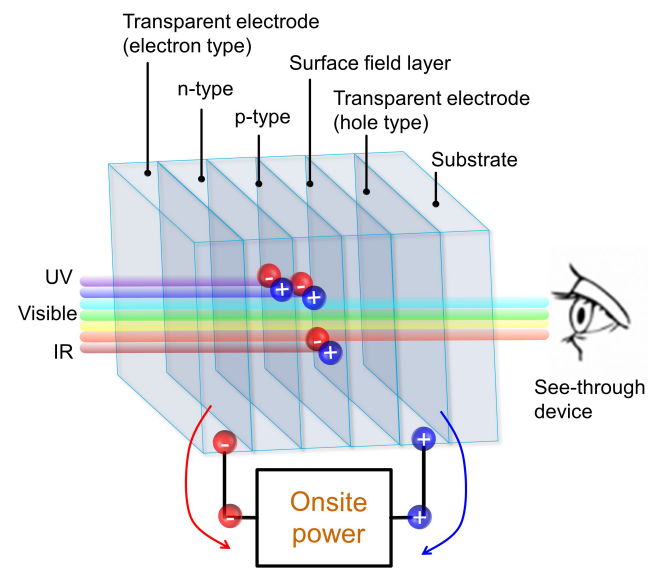

Figure 2. Schematic illustration of inorganic TPVs enabling onsite power production and transparent device farication. 
Table II. Processing parameters and optical and electronic properties of metal-oxide films grown using different sputtering methods, where $E_{g}$ is band gap, $T$ is transmittance, $t$ is thickness of the film, $T_{p}$ is processing temperature, $\sigma$ is conductivity type ( $n$-type or $p$-type), $\rho$ is resistivity, $\mu$ is mobility, and $N$ is carrier concentration.

\begin{tabular}{|c|c|c|c|c|c|c|c|c|c|c|}
\hline Material & $\begin{array}{l}\text { Processings } \\
\text { parameters }\end{array}$ & $\begin{array}{c}T_{p} \\
\left({ }^{\circ} \mathrm{C}\right) \\
\end{array}$ & $\begin{array}{c}t \\
(\mathrm{~nm})\end{array}$ & $\sigma$ & $\begin{array}{c}E_{g} \\
(\mathrm{eV})\end{array}$ & $\begin{array}{c}T \\
(\%)\end{array}$ & $\begin{array}{c}\rho \\
(\Omega \cdot \mathrm{cm})\end{array}$ & $\begin{array}{c}N \\
\left(\mathrm{~cm}^{-3}\right)\end{array}$ & $\begin{array}{c}\mu \\
\left(\mathrm{cm}^{2} / \mathrm{Vs}\right) \\
\end{array}$ & Ref. \\
\hline \multirow{4}{*}{$\mathrm{NiO}$} & $\begin{array}{c}\sim 150 \mathrm{~W}(\mathrm{RF}) \\
\mathrm{pO}_{2} \sim 0.5 \%\end{array}$ & 25 & 300 & $p$ & \multirow{2}{*}{$3.5-4$} & 80 & $10^{4}$ & $10^{14}$ & 50 & {$[37]$} \\
\hline & $\begin{array}{l}\sim 200 \mathrm{~W}(\mathrm{DC}) \\
\mathrm{Ar}: \mathrm{O}_{2} \sim 70: 3\end{array}$ & 25 & 120 & $p$ & & - & 9665 & $6.42 \times 10^{14}$ & 1.01 & {$[52]$} \\
\hline & \multirow{2}{*}{ Power $\sim 50 \mathrm{~W}$} & 25 & 100 & $p$ & 3.8 & 80 & 1503 & $6.08 \times 10^{14}$ & 6.73 & \multirow{2}{*}[53]{} \\
\hline & & 400 & 60 & $p$ & 3.2 & 60 & 72 & $3.87 \times 10^{16}$ & 2.23 & \\
\hline $\mathrm{Cu}_{2} \mathrm{O}$ & $\begin{array}{c}\sim 720 \mathrm{~W} / \mathrm{cm}^{2}(\mathrm{DC}) \\
\mathrm{Ar}: \mathrm{O}_{2} \sim 90: 10\end{array}$ & 350 & 400 & $p$ & 2.48 & - & 22 & $4.41 \times 10^{18}$ & 57.5 & {$[54]$} \\
\hline \multirow[t]{2}{*}{$\mathrm{CuGaO}_{2}$} & \multirow[t]{2}{*}{$\begin{array}{c}250 \mathrm{~W} \\
\mathrm{pO}_{2} \sim 45 \%\end{array}$} & 750 & 686 & $p$ & 3.45 & poor & 57.4 & - & - & [55] \\
\hline & & 700 & 500 & $p$ & 3.6 & 80 & 15 & $1.7 \times 10^{18}$ & 0.23 & {$[56]$} \\
\hline \multirow{2}{*}{$\mathrm{CuCrO}_{2}$} & $\begin{array}{c}\sim 200 \mathrm{~W} \\
\mathrm{pN}_{2} \sim 40 \%\end{array}$ & 625 & 150 & $p$ & 3 & 73 & 53 & $1.46 \times 10^{19}$ & 0.8 & {$[57]$} \\
\hline & $\begin{array}{c}\text { Power } \sim 250 \mathrm{~W} \\
\mathrm{pO}_{2} \sim 70 \% \\
\end{array}$ & 625 & - & $p$ & 3.14 & 65 & 4.31 & $4.17 \times 10^{18}$ & 1.22 & {$[58]$} \\
\hline $\mathrm{CuFeO}_{2}$ & $\begin{array}{c}\sim 4 \mathrm{~W} / \mathrm{cm}^{2} \\
\mathrm{pO}_{2} \sim 1 \%\end{array}$ & 25 & 130 & & 3.25 & 60 & 11.76 & $2.80 \times 10^{17}$ & 1.89 & [59] \\
\hline $\mathrm{CuAlO}_{2}$ & $\begin{array}{c}\sim 750 \mathrm{~V}(\mathrm{DC}) \\
\mathrm{pN}_{2} 6 \times 10^{-2} \mathrm{pa}\end{array}$ & 300 & - & $p$ & 3.46 & 69 & 1.95 & $4 \times 10^{17}$ & 9.4 & {$[47]$} \\
\hline \multirow{2}{*}{$\mathrm{ZnO}$} & $\sim 200 \mathrm{~W}$ & 25 & 240 & $n$ & 3.2 & - & $3.5 \times 10^{3}$ & - & 1 & [48] \\
\hline & $\sim 300 \mathrm{~W}$ & 25 & 470 & $n$ & 3.3 & 70 & - & $5 \times 10^{17}$ & - & [39] \\
\hline \multirow{2}{*}{$\mathrm{AZO}$} & $\begin{array}{c}\mathrm{Al}_{2} \mathrm{O}_{3}: \mathrm{ZnO} \sim 0.5 \\
\sim 225 \mathrm{~W}\end{array}$ & 330 & 640 & $n$ & 3.66 & 70 & 4.3 & $3.6 \times 10^{20}$ & 41.3 & [49] \\
\hline & $\begin{array}{c}2 \% \text { of } \mathrm{Al} \text { in } \mathrm{ZnO} \\
\quad \sim 300 \mathrm{~W}\end{array}$ & 550 & 15 & $n$ & 3.42 & 70 & - & $1.5 \times 10^{20}$ & 3 & [39] \\
\hline $\mathrm{TiO}_{2}$ & $\begin{array}{c}\sim 300 \mathrm{~W} \\
\mathrm{Ar} \sim 50 \mathrm{sccm} \\
\mathrm{O}_{2} \sim 2 \mathrm{sccm}\end{array}$ & 500 & 5 & $n$ & 3.2 & 70 & 0.1 & $3 \times 10^{19}$ & $0.1-4$ & [43] \\
\hline $\mathrm{SnO}_{2}$ & $\begin{array}{c}\sim 30 \mathrm{~W} \\
\mathrm{Ar} \sim 60 \mathrm{sccm} \\
\mathrm{O}_{2} \sim 9 \mathrm{sccm}\end{array}$ & 150 & 300 & $n$ & $3.6-4$ & 80 & 0.0419 & $3.57 \times 10^{19}$ & 3.37 & [50] \\
\hline $\mathrm{Zn}_{2} \mathrm{SnO}_{4}$ & $\begin{array}{c}\sim 50 \mathrm{~W} \\
\text { Ar: } \mathrm{O}_{2} \sim 99: 1\end{array}$ & 300 & 100 & $n$ & 3.65 & $\sim 60$ & 2.1 & $10^{17}$ & 14.5 & [51] \\
\hline
\end{tabular}

thin $\mathrm{NiO}$ film induces the effect of electron blocking with a high carrier mobility $\left(\sim 1-10 \mathrm{~cm}^{2} / \mathrm{Vs}\right)$, i.e., an efficient hole-transporting property $[52,53]$. The high exciton-binding energy $(110 \mathrm{meV})$ of the $\mathrm{NiO}$ films enables a lower thermalization loss of the exciton [69]. These excellent optical and electrical properties make it a suitable material for a wide range of applications, such as an anode buffer layer in organic solar cells, a hole transport layer in PSC, radiation detectors, laser materials, thermoelectric devices, and so forth. Further tuning of the electrical properties (carrier concentration, hole mobility, and work function) is attained through doping with $\mathrm{Cu}^{+}, \mathrm{Ag}^{+}, \mathrm{Cs}^{+}, \mathrm{Li}^{+}$, and $\mathrm{Mg}^{2+}$, which can improve the reported PCE of the PSCs [30,70,71]. Although $\mathrm{NiO}$ thin films have been prepared using various wet chemical routes, chemical vapor deposition, and physical vapor deposition, TPV technology is mainly focused on large-scale preparation methods like reactive sputtering $[33,39,68]$. Sputtering techniques have the advantage of realizing higher uniformity over a large surface area, a higher film density, and stronger adhesion. Warasawa et al. [37] prepared $\mathrm{NiO}$ films using the radio frequency (RF) reactive sputtering technique for TPVs in which an RF power of $150 \mathrm{~W}$ was applied to the Ni target in the presence of $\mathrm{Ar}$ and $\mathrm{O}_{2}$ gases with an $\mathrm{O}_{2}$ fraction $\left(\mathrm{O}_{2} /\left(\mathrm{Ar}+\mathrm{O}_{2}\right)\right)$ of $\sim 0.5 \%$; the prepared film exhibited a comparatively high mobility of $\sim 50 \mathrm{~cm}^{2} /$ Vs. They reported a decrease in AVT from 80 to $50 \%$ with a decrease in the electrical resistivity from $10^{4}$ to $10^{3} \Omega \cdot \mathrm{cm}$. NiO consists of both $\mathrm{Ni}^{2+}$ and $\mathrm{Ni}^{3+}$ oxidation states, and its p-type conductivity is improved by increasing the concentration of $\mathrm{Ni}^{3+}$, via an $\mathrm{O}$-rich growth condition. This condition results in the formation of $\mathrm{Ni}$ vacancies $\left(\mathrm{V}_{\mathrm{Ni}}\right)$ and/or interstitial $\mathrm{O}$ in the $\mathrm{NiO}$ crystal lattice. How- ever, the increased $\mathrm{V}_{\mathrm{Ni}}$ concentrations result in a decrease in the AVT because of the visible light absorbance of $\mathrm{Ni}^{3+}$. Hence, the preparation of $\mathrm{NiO}$ films, using the reactive sputtering technique under a high $\mathrm{O}_{2}$ fraction, results in a decrease in the AVT $(\sim 40 \%)$ with an increase in the p-type conductivity [37].

Cuprous oxide $\left(\mathrm{Cu}_{2} \mathrm{O}\right)$ is a well-known p-type semiconductor with a comparatively high band gap of $2.38-2.51 \mathrm{eV}$, high carrier mobility, high diffusion length, and high work function $(\sim 5.0 \mathrm{eV})$. It has a cubic crystal structure, and each unit cell consists of four $\mathrm{Cu}$ (at the fcc position) and two $\mathrm{O}$ atoms (at tetrahedral sites). The p-type conductivity of $\mathrm{Cu}_{2} \mathrm{O}$ is due to the presence of $\mathrm{Cu}$ vacancies $\left(\mathrm{V}_{\mathrm{Cu}}\right)[60,72]$.

$\mathrm{Cu}$ delafossite metal oxides, such as $\mathrm{CuGaO}_{2}, \mathrm{CuCrO}_{2}, \mathrm{CuAlO}_{2}$, and $\mathrm{CuFeO} 2$, have recently attracted significant attention as suitable materials for hole transport layers in PSC. The delafossite metal oxides have an $\mathrm{A}^{+} \mathrm{B}^{3+} \mathrm{O}_{2}$ structure, in which a sheet of monovalent $\mathrm{A}$ ions are stacked between the edge-shared octahedral $\mathrm{BO}_{6}$ ions. The $\mathrm{Cu}$ delafossite metal oxides are p-type semiconductors with low electron affinities $(\sim 2.1 \mathrm{eV})$, high carrier mobilities $\left(\sim 100 \mathrm{~cm}^{2} / \mathrm{Vs}\right)$, and large diffusion lengths [30]. These materials exhibit a direct energy band gap in the range of 3.2 to $3.6 \mathrm{eV}$, with a high visible-light transmittance $(\sim 80 \%)$, which makes them a suitable choice for TPVs. The p-type conductivity of these materials is correlated with the formation of $\mathrm{Cu}$ defects and $\mathrm{O}$ interstitials [73]. Yu et al. [55] prepared $\mathrm{CuGaO}_{2}$ thin films using a reactive magnetron sputtering technique, in which a sputtering power of $250 \mathrm{~W}$ was applied to $\mathrm{Cu}$ and $\mathrm{Ga}$ targets in the presence of Ar and $\mathrm{O}_{2}$ as the sputtering gases $\left(\mathrm{O}_{2} /\left(\mathrm{O}_{2}+\mathrm{Ar}\right)\right.$ at $\left.\sim 45 \%\right)$ at room temperature, followed by annealing $\left(700-900^{\circ} \mathrm{C}\right)$ in an $\mathrm{N}_{2}$ at- 


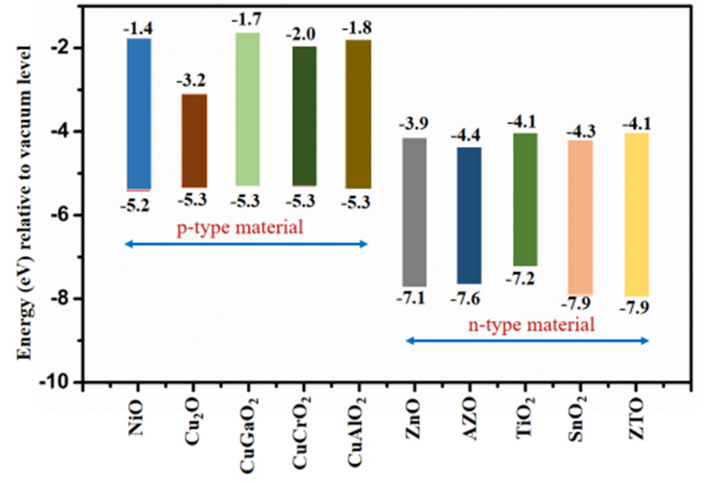

Figure 3. Energy-level diagram of widely used p-type ( $\mathrm{NiO}$ [33], $\mathrm{Cu}_{2} \mathrm{O}$ [60], $\mathrm{CuGaO}_{2}$ [61], $\mathrm{CuCrO}_{2}$ [62], and $\mathrm{CuAlO}_{2}$ [63]) and n-type ( $\mathrm{ZnO}$ [33], AZO [64], $\mathrm{TiO}_{2}$ [65], $\mathrm{SnO}_{2}$ [67], and ZTO [66]) metal oxides.

mosphere. At an annealing temperature of $700^{\circ} \mathrm{C}$, both the $\mathrm{CuO}$ and $\mathrm{CuGaO}_{4}$ phases are formed along with $\mathrm{CuGaO}_{2}$, whereas in the temperature range of $750-850^{\circ} \mathrm{C}$, a single phase of $\mathrm{CuGaO}_{2}$ is formed. $\mathrm{A}$ further increase in the annealing temperature results in the formation of $\mathrm{Ga}_{2} \mathrm{O}_{3}$ at a secondary phase. The prepared single phase of the $\mathrm{CuGaO}_{2}$ film (annealed at $750^{\circ} \mathrm{C}$ ) exhibits a direct energy band gap of $3.45 \mathrm{eV}$, whereas the film annealed at $700^{\circ} \mathrm{C}$ exhibits a direct energy band gap of $2.44 \mathrm{eV}$ [55]. For the application of TPVs, Tonooka et al. [36] prepared $\mathrm{CuAlO}_{2}$ films using the pulsed layer deposition (PLD) technique with a substrate temperature of $400^{\circ} \mathrm{C}$ in the presence of 2 mTorr of $\mathrm{O}_{2}$. The deposited film exhibited both direct and indirect band gaps of 1.8 and $3.5 \mathrm{eV}$, respectively, with an electrical resistivity of $\sim 10 \Omega \cdot \mathrm{cm}$. They reported that the amorphous nature of the prepared film results in an increase in the indirect optical absorption with a shift in the absorption edge toward the lower energy side.

Table II shows a comparatively high reaction temperature for $\mathrm{CuCr}$ $\mathrm{O}_{2}$ and $\mathrm{CuGaO}_{2}$, and such a high temperature is disadvantageous for the real-life applications of TPVs. In contrast, Zhang et al. [61] prepared $\mathrm{CuGaO}_{2}$ nanoplates using a microwave-assisted hydrothermal method (reaction temperature $\sim 230^{\circ} \mathrm{C}$, reaction time of $\sim 2 \mathrm{~h}$ ). Later the spin coating $\left(3,000 \mathrm{rpm}\right.$ for $60 \mathrm{~s}$, followed by drying at $100^{\circ} \mathrm{C}$ for $1 \mathrm{~h})$ technique was used for the preparation of $\mathrm{CuGaO}_{2}$ films. Furthermore, PSCs, fabricated with a device configuration of $\mathrm{FTO} / \mathrm{TiO}_{2} /$ $\mathrm{CH}_{3} \mathrm{NH}_{3} \mathrm{PbI}_{3-1} \mathrm{Cl}_{3} / \mathrm{CuGaO}_{2} / \mathrm{Au}$ (where FTO is fluorine-doped tin oxide), exhibited a PCE of $18.51 \%$. Similarly, Jeong et al. [62] used a lowtemperature hydrothermal method (at a reaction temperature of 240 ${ }^{\circ} \mathrm{C}$, with a reaction time of $60 \mathrm{~h}$ ) for the preparation of $\mathrm{CuCrO}_{2}$ as a hole transport layer for PSCs with a PCE of $13.1 \%$. Thus, a wet chemical route is another suitable low-temperature pathway for the preparation of high-formation-temperature metal oxides.

$\mathrm{ZnO}$ has garnered significant attention as an n-type material for a wide range of applications. $\mathrm{ZnO}$ has a wurtzite hexagonal crystal structure with a direct energy band gap of $\sim 3.2 \mathrm{eV}$, high electron mobility, and large exciton binding energy $(60 \mathrm{meV})$, rendering it feasible for the fabrication of $\mathrm{p}-\mathrm{n}$ heterojunctions [64]. The tetrahedral coordination in $\mathrm{ZnO}$ results in a non-symmetric structure with piezoelectric and pyroelectric properties. Patel et al. [69] prepared $\mathrm{ZnO}$ films for TPV applications, using a sputtering technique with an RF power of $300 \mathrm{~W}$ applied to the $\mathrm{ZnO}$ target.

$\mathrm{TiO}_{2}$ is another widely used n-type polymorphic semiconductor with anatase, brookite, and rutile crystal structures. Among these, the rutile structure is highly stable at macroscopic sizes, whereas the anatase occurs only in nanoscopic sizes. Brookite is the rarest naturally occurring form of $\mathrm{TiO}_{2}$. Anantase- $\mathrm{TiO}_{2}$ exhibits a direct energy band gap of $3.2 \mathrm{eV}$ with an electrical resistivity of $\sim 0.1 \Omega \cdot \mathrm{cm}$, a donor concentration of $\sim 10^{17} \mathrm{~cm}^{-3}$, and a bulk mobility in the range of $0.1-4.0$ $\mathrm{cm}^{2} / \mathrm{Vs}$ [74]. Patel et al. [34] prepared $\mathrm{TiO}_{2}$ films using direct current (DC) reactive sputtering with a DC power of $300 \mathrm{~W}$ applied to a $\mathrm{Ti}$ target in the presence of an $\mathrm{Ar}$ and $\mathrm{O}_{2}$ flow rate of 50 and $2 \mathrm{sccm}$, respectively, at a substrate temperature of $500^{\circ} \mathrm{C}$.

Sn-based metal oxides are attractive owing to their excellent optoelectronic properties, which are either similar to or better than those of $\mathrm{TiO}_{2}$. The low electron mobility of $\mathrm{TiO}_{2}$ causes inadequate charge separation at the heterojunction. $\mathrm{SnO}_{2}$ is a wide-band-gap (3.6-4.0 eV) n-type semiconductor with a rutile crystal structure. The highly efficient charge extraction property of $\mathrm{SnO}_{2}$ is mainly due to its deep conduction band and high carrier mobility $\left(100-200 \mathrm{~cm}^{2} / \mathrm{Vs}\right)[50]$. $\mathrm{Zn}_{2} \mathrm{SnO}_{4}(\mathrm{ZTO})$ is another well-known n-type semiconductor with a wide direct-energy band gap of $3.8 \mathrm{eV}$ and refractive index of $\sim 2$, which allows a high visible-light transmittance [51]. The conductionband edge position of ZTO is similar to that of $\mathrm{TiO}_{2}$, and it exhibits a high electron mobility of $\sim 10-15 \mathrm{~cm}^{2} / \mathrm{Vs}$, which allows $\sim 10$ times faster electron transport with a higher charge collection efficiency than that of $\mathrm{TiO}_{2}$. The $\mathrm{O}$ vacancy $\left(\mathrm{V}_{\mathrm{O}}\right)$ in $\mathrm{ZTO}$ acts as a double-ionized donor that contributes two electrons to the electrical conduction, such that the carrier concentration can be improved by annealing under a reducing atmosphere [32]. Although these Sn-based transparent conducting oxides have gained notable attention as electron-transportlayer materials for PSCs, they have not been used in TPVs until recently.

\section{Photovoltaic performance of inorganic TPVs}

Tonooka et al. [36] fabricated an ITO $(200 \mathrm{~nm}) / \mathrm{CuAlO}_{2}(400 \mathrm{~nm}) / \mathrm{n}$ $\mathrm{ZnO}(400 \mathrm{~nm}) / \mathrm{n}^{+}-\mathrm{ZnO}(200 \mathrm{~nm}) \mathrm{TPV}$ (here, ITO is indium tin oxide) using the PLD technique. The fabricated device exhibited a weak photovoltage of $80 \mathrm{mV}$ under a light-emitting diode (wavelength, $\lambda$ $\sim 470 \mathrm{~nm}$, intensity, I $\sim 37 \mathrm{~W} / \mathrm{cm}^{2}$ ). The low performance of the device is mainly due to the amorphous nature of the $\mathrm{CuAlO}_{2}$ film deposited at a very-low substrate temperature of $400^{\circ} \mathrm{C}$. Warasawa et al. [37] produced an $\mathrm{NiO}$-based TPV with a device configuration of $\mathrm{ZnO}: \mathrm{Ga}(500 \mathrm{~nm}) / \mathrm{ZnO}(100 \mathrm{~nm}) / \mathrm{NiO}(300 \mathrm{~nm})$, using the reactive sputtering technique. The fabricated device exhibited a visible-light transmittance of $70 \%$ and PCE $<0.01 \%$. The reported low values of short-circuit current density $\left(\mathrm{J}_{\mathrm{sc}}\right)$ and open-circuit voltage $\left(\mathrm{V}_{\mathrm{oc}}\right)$ can be correlated with the low crystal quality of $\mathrm{NiO}$ films and formation of defects at the $\mathrm{ZnO} / \mathrm{NiO}$ interface due to the sputtering process. Karsthof et al. [38] fabricated an $\mathrm{NiO} / \mathrm{ZnO} \mathrm{TPV}$, in which the $\mathrm{ZnO}$ and $\mathrm{NiO}$ films were deposited using PLD and reactive DC sputtering techniques, respectively. The applied DC power for the Ni target was $30 \mathrm{~W}$ with an $\mathrm{Ar} / \mathrm{O}_{2}$ flow ratio of 1:1. The device, with a configuration of $\mathrm{Al}_{2} \mathrm{O}_{3} / \mathrm{AZO} / \mathrm{ZnO} / \mathrm{NiO} / \mathrm{Au}$, exhibited $46 \%$ transmittance in the visible range, with a PCE of $0.1 \%$ for solar spectrum and $3.1 \%$ for UV light illumination. The authors commented that the PCE could be further improved by reducing the density of the $\mathrm{ZnO} / \mathrm{NiO}$ interface defects by introducing a buffer layer or through a surface passivation treatment.

Patel et al. [33] fabricated an FTO/ZnO $(100 \mathrm{~nm}) / \mathrm{NiO}(35 \mathrm{~nm}) / \mathrm{Ag}$ TPV. The NiO layer was deposited using the DC reactive sputtering technique, wherein the Ni target was sputtered with a DC power of $50 \mathrm{~W}$ in the presence of $\mathrm{Ar}(30 \mathrm{sccm})$ and $\mathrm{O}_{2}(4 \mathrm{sccm})$ gases. The prepared $\mathrm{NiO} / \mathrm{ZnO}$ heterojunction exhibited a potential barrier of $0.8 \mathrm{eV}$, offering a high built-in electric field and low dark current $\left(J_{\text {dark }}\right)$. Because $J_{\text {dark }}$ is the movement of charges under equilibrium conditions, the low $J_{\text {dark }}$ value indicates a better-quality interface. The high builtin electric field separated the electron-hole pairs generated through UV photon absorption at the interface. Finally, the fabricated device exhibited a visible-range transmittance of $69.6 \%$ with a PCE of $6 \%$ under UV illumination $\left(\lambda \sim 365 \mathrm{~nm}, \mathrm{I} \sim 10 \mathrm{~mW} / \mathrm{cm}^{2}\right)$. Further, Ban et al. [39] introduced an aluminum-doped zinc oxide (AZO) layer as the back surface field layer of a large-scale TPV $\left(1 \mathrm{inch}^{2}\right)$, with a device configuration of FTO $(500 \mathrm{~nm}) / \mathrm{AZO}(10 \mathrm{~nm}) / \mathrm{ZnO}(400 \mathrm{~nm}) / \mathrm{NiO}(75$ 
(a)

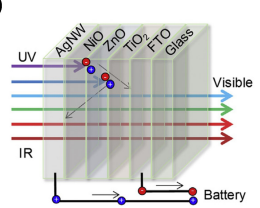

(b)

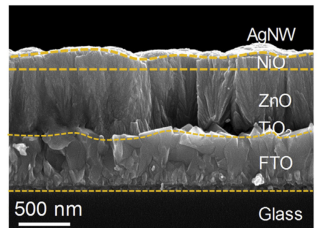

(c)

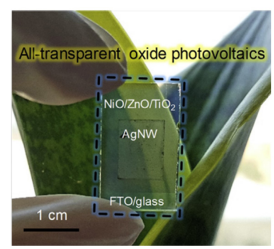

(d)

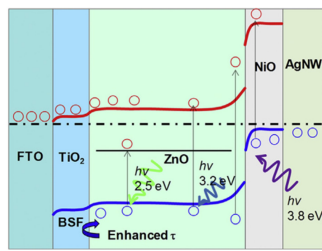

Figure 4. Oxide thin-film-based TPVs. (a) Device architecture. (b) Cross-sectional field emission scanning electron microscopy image of a TPV device with a configuration of $\mathrm{FTO} / \mathrm{TiO}_{2} / \mathrm{ZnO} / \mathrm{NiO} / \mathrm{AgNW}$. (c) Oxide-based TPV devices. (d) Energyband diagram showing the enhanced carrier lifetime with the incorporation of an ultrathin $\mathrm{TiO}_{2}(5 \mathrm{~nm})$ layer. Reproduced with permission from [78], Copyright 2020, Elsevier.

$\mathrm{nm}$ )/AgNW. The NiO layer was deposited under optimized sputtering conditions. The device exhibited a high visible-light transmittance of $>70 \%$. In the absence of the AZO layer, the device possessed a positive banding of $25 \mathrm{meV}$, which caused recombination of the photogenerated charge carriers. In contrast, when the AZO layer was introduced as the surface field layer, the recombination of the electrons at the top surface, owing to the introduced barrier height of $-0.35 \mathrm{eV}$ for holes, was prevented. Accordingly, by introducing an AZO layer, the efficiency was significantly improved from 0.42 to $3.13 \%$ under UV illumination ( $\lambda$ of $\sim 365 \mathrm{~nm}$ ) with an intensity of $13 \mathrm{~mW} / \mathrm{cm}^{-2}$. Similarly, by introducing the AZO layer, the PCE was improved from 0.38 to $0.56 \%$ under the AM 1.5 spectrum.

Rana et al. [40] also prepared a $\mathrm{Cu}-\mathrm{Cu}_{2} \mathrm{O} / \mathrm{ZnO}$ heterojunction for a TPV with a device configuration of $\mathrm{FTO} / \mathrm{ZnO}(250 \mathrm{~nm}) / \mathrm{Cu}_{2} \mathrm{O}-\mathrm{Cu}$ $(100 \mathrm{~nm}) / \mathrm{AgNW}$. The $\mathrm{Cu}-\mathrm{Cu}_{2} \mathrm{O}$ layer was deposited using a reactive sputtering technique with a $\mathrm{Cu}$ target and an applied DC power of 80 $\mathrm{W}$ in the presence of $\mathrm{Ar}$ and $\mathrm{O}_{2}$ gases $\left(\mathrm{Ar} / \mathrm{O}_{2} \sim 10: 1\right)$. The heterojunction was annealed at $300^{\circ} \mathrm{C}$ for $10 \mathrm{~min}$, in vacuum ( $8 \mathrm{mTorr}$ ). The deposited $\mathrm{Cu}-\mathrm{Cu}_{2} / \mathrm{ZnO}$ film exhibited a transmittance of $80 \%$, which was reduced to $55 \%(600-1,100 \mathrm{~nm})$ after annealing. The fabricated device exhibited an improvement in the PCE from 0.093 to $0.405 \%$ due to annealing ( $\mathrm{I} \sim 70 \mathrm{~mW} / \mathrm{cm}^{2}$ ), indicating the formation of mixed oxide phases, which in turn improved the electronic properties and charge carrier transport. In the same study, AZO was introduced as a surface field layer, with a device configuration of ITO $(250 \mathrm{~nm}) / \mathrm{AZO}$ $(200 \mathrm{~nm}) / \mathrm{ZnO}(200 \mathrm{~nm}) / \mathrm{Cu}_{2} \mathrm{O}(100 \mathrm{~nm}) / \mathrm{AgNW}$. The fabricated device exhibited $80 \%$ transmittance in the $600-900 \mathrm{~nm}$ range, with an efficiency of $0.46 \%$ (I $\sim 100 \mathrm{~mW} / \mathrm{cm}^{2}$ ) [41]. Patel et al. [42,75,76] also fabricated an $\mathrm{FTO} / \mathrm{ZnO} / \mathrm{Co}_{3} \mathrm{O}_{4} / \mathrm{NiO} / \mathrm{AgNW} \mathrm{TPV}$ using the sputtering technique. Energy-band diagram-based studies have shown that $\mathrm{Co}_{3} \mathrm{O}_{4}$ increases the built-in electric field and reduces the band offset of the valence band. Accordingly, the PCE was improved from 0.36 to $1.30 \%$, under the AM 1.5 spectrum $\left(\mathrm{I} \sim 100 \mathrm{~mW} / \mathrm{cm}^{2}\right)$, by incorporating an ultrathin layer $(50 \mathrm{~nm})$ of $\mathrm{Co}_{3} \mathrm{O}_{4}$. However, the average visible-light (400-800 $\mathrm{nm}$ ) transmittance was reduced from $>60 \%$ to $>30 \%$ because of the incorporation of $\mathrm{Co}_{3} \mathrm{O}_{4}$.

To improve the PCE further, Nguyen et al. [8, 43, 77] introduced $\mathrm{TiO}_{2}$ as a surface field layer with a device configuration of $\mathrm{FTO} / \mathrm{TiO}_{2}$ $(5 \mathrm{~nm}) / \mathrm{ZnO}(470 \mathrm{~nm}) / \mathrm{NiO}(200 \mathrm{~nm}) / \mathrm{AgNW}$, in which the metal oxide layers were deposited using the sputtering technique (Fig. 4). The incorporation of $\mathrm{TiO}_{2}$ as the surface field layer caused a 20 -fold decrease in the $J_{\text {dark }}$ value, which in turn increased the PCE from 3.09 to $6.10 \%$ under UV illumination $\left(\lambda \sim 365 \mathrm{~nm}\right.$ and $\left.\mathrm{I} \sim 8 \mathrm{~mW} / \mathrm{cm}^{2}\right)$.

Further, Patel et al. [34] enhanced the photovoltaic performance of
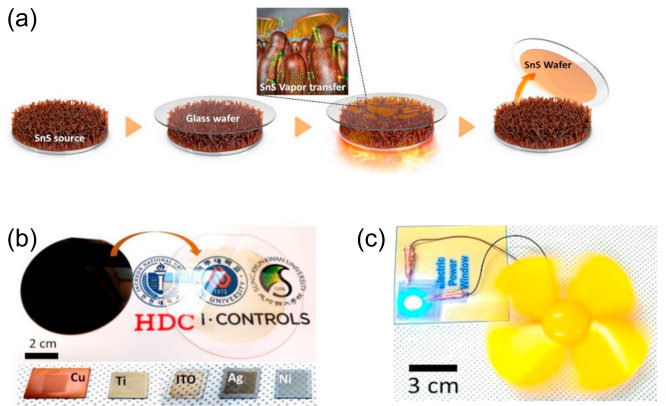

Figure 5. (a) Schematic diagram showing the proximity vapor-transfer deposition of SnS thin films. (b) Wafer-scale transfer of SnS films on various substrates. (c) 2D-layer embedded TPV device demonstrating onsite power production. Reproduced with permission from [34], Copyright 2019, Elsevier.

a TPV by introducing a wafer-scale two-dimensional (2D) absorber layer material in the TPV device. The device configuration was glass/ $\mathrm{FTO} / \mathrm{TiO}_{2} / \mathrm{SnS} / \mathrm{NiO} / \mathrm{Au}$ film, in which the $\mathrm{SnS}$ nanoplatelets were prepared through a novel proximity vapor-transfer method (Fig. 5). The prepared $S$-rich SnS nanoplatelets had a thickness of $10-15 \mathrm{~nm}$, and exhibited $p$-type conductivity with a carrier concentration of $\sim 10^{17}$ $\mathrm{cm}^{-3}$. Furthermore, the $\mathrm{SnS}$ nanoplatelets exhibited a good performance relative to that of the TPV without SnS or with conventional SnS layers. In this device configuration, the $\mathrm{TiO}_{2}$ layer $(80 \mathrm{~nm})$, deposited using the reactive sputtering method, acts as the $n$-type layer. $\mathrm{The} \mathrm{NiO}(30 \mathrm{~nm})$ and $\mathrm{Au}(20 \mathrm{~nm})$ films were deposited using reactive sputtering and thermal evaporation, respectively. The prepared TPV exhibited $60 \%$ visible-light transmission with a PCE of $\sim 13 \%$ under UV light $\left(\lambda \sim 365 \mathrm{~nm}\right.$ and $\left.\mathrm{I} \sim 60 \mathrm{~mW} / \mathrm{cm}^{2}\right)$. Furthermore, the device generated an output power of $6 \mathrm{~mW}$ under UV light ( $\lambda$ of $\sim 365 \mathrm{~nm}$ and $\mathrm{I}$ of $\left.\sim 70 \mathrm{~mW} / \mathrm{cm}^{2}\right)$. Kim et al. $[15,79,80]$ demonstrated an Si-embedded TPV with a device configuration of glass/FTO/AZO $(10 \mathrm{~nm}) / \mathrm{ZnO}(400 \mathrm{~nm}) / \mathrm{Si}(15 \mathrm{~nm}) / \mathrm{NiO}(80 \mathrm{~nm})$, wherein the Si thin films were deposited using plasma-enhanced chemical vapor deposition (Fig. 6). This device configuration enabled photon absorption from UV to longer wavelengths owing to the introduction of a Si layer, as a functional layer with a band gap of $1.8 \mathrm{eV}$, between the $\mathrm{ZnO}$ and $\mathrm{NiO}$ films. The large barrier height at the $\mathrm{ZnO} / \mathrm{NiO}$ heterojunction could be reduced with the introduction of $\mathrm{Si}$, which has an intermedi-
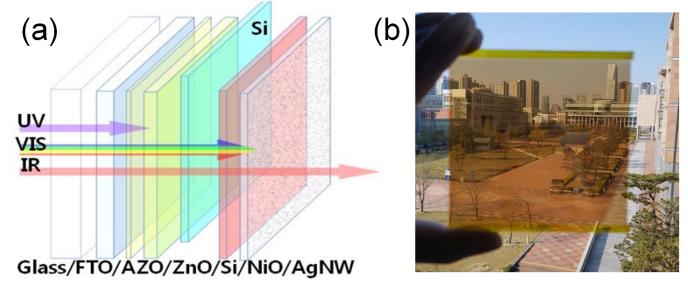

(c)

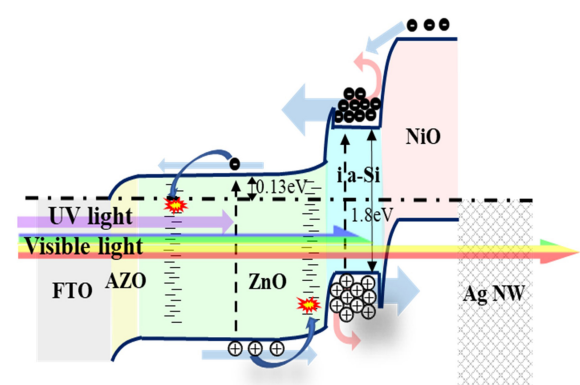

Figure 6. Si thin-film-based TPVs. (a) Device architecture. (b) Original photograph of the large-scale device with an AVT of $40 \%$ and (c) energy-band diagram of the device with a configuration of FTO/AZO/ZnO $(400 \mathrm{~nm}) / \mathrm{Si}(15 \mathrm{~nm}) / \mathrm{NiO}(80$ $\mathrm{nm}$ )/AgNW. Reproduced with permission from [15], Copyright 2020, Elsevier. 
Table III. Photovoltaic performance in terms of short-circuit current density $\left(J_{\text {sc }}\right)$, open-circuit voltage $\left(V_{\text {oc }}\right)$, fill factor $(F F)$, efficiency $(\eta)$, and device active area $(A)$, along with the AVT values of different TPV devices. In the measurement condition light wavelength $\lambda$ is in $\mathrm{nm}$ and light intensity $(P)$ in $\mathrm{mW} / \mathrm{cm}^{2}$.

\begin{tabular}{|c|c|c|c|c|c|c|c|c|}
\hline Configuration & $\begin{array}{r}\text { AVT } \\
(\%)\end{array}$ & $\begin{array}{c}J_{\mathrm{sc}} \\
\left(\mathrm{mA} / \mathrm{cm}^{2}\right)\end{array}$ & $\begin{array}{c}V_{\mathrm{oc}} \\
(\mathrm{mV})\end{array}$ & $\begin{array}{l}\text { FF } \\
(\%)\end{array}$ & $\begin{array}{c}\eta \\
(\%)\end{array}$ & $\begin{array}{c}A \\
\left(\mathrm{~mm}^{2}\right)\end{array}$ & $\begin{array}{l}\text { Measurement } \\
\text { condition }\end{array}$ & Ref. \\
\hline $\mathrm{ITO} / \mathrm{CuAlO}{ }_{2} / \mathrm{n}-\mathrm{ZnO} / \mathrm{n}^{+}-\mathrm{ZnO}$ & 43 & - & 80 & - & - & 7 & $\begin{array}{c}\lambda=470 \\
P=37 \mathrm{~W} / \mathrm{cm}^{2}\end{array}$ & {$[36]$} \\
\hline $\mathrm{ZnO}: \mathrm{Ga} / \mathrm{ZnO} / \mathrm{NiO}$ & 70 & 0.002 & 170 & 27 & 0.01 & - & AM 1.5 & [37] \\
\hline $\mathrm{Al}_{2} \mathrm{O}_{3} / \mathrm{AZO} / \mathrm{ZnO} / \mathrm{NiO} / \mathrm{Au}$ & 46 & 0.5 & 520 & 42 & $\begin{array}{c}0.1 \\
\eta_{\mathrm{uv}} 3.1\end{array}$ & 0.23 & AM 1.5 & [38] \\
\hline $\mathrm{FTO} / \mathrm{ZnO} / \mathrm{NiO} / \mathrm{Ag}$ & 70 & 2.7 & 532 & 41.8 & 6 & 9 & $\lambda=365 \mathrm{~nm}, P=10$ & {$[33]$} \\
\hline $\mathrm{FTO} / \mathrm{ZnO} / \mathrm{NiO} / \mathrm{AgNW}$ & \multirow{4}{*}{70} & 0.79 & 770 & 62.4 & 0.38 & \multirow{2}{*}{\multicolumn{2}{|c|}{ AM 1.5}} & \multirow{4}{*}[39]{} \\
\hline $\mathrm{FTO} / \mathrm{AZO} / \mathrm{ZnO} / \mathrm{NiO} / \mathrm{AgNW}$ & & 0.80 & 815 & 86.1 & 0.56 & & & \\
\hline $\mathrm{FTO} / \mathrm{ZnO} / \mathrm{NiO} / \mathrm{AgNW}$ & & & 350 & 26 & 0.42 & \multirow[t]{2}{*}{645} & $\lambda=365 \mathrm{~nm}$ & \\
\hline FTO/AZO/ZnO/NiO/AgNW & & & 450 & 40 & 3.13 & & $P=13$ & \\
\hline $\begin{array}{c}\mathrm{FTO} / \mathrm{ZnO} / \mathrm{Cu}_{2} \mathrm{O}-\mathrm{Cu} / \mathrm{AgNW} \\
\text { (as deposited) }\end{array}$ & 80 & 0.412 & 600 & 26.49 & 0.093 & \multirow[t]{2}{*}{100} & AM 1.5 & \multirow[t]{2}{*}[40]{} \\
\hline $\begin{array}{l}\mathrm{FTO} / \mathrm{ZnO} / \mathrm{Cu}_{2} \mathrm{O}-\mathrm{Cu} / \mathrm{AgNW} \\
\text { (annealed, } 300^{\circ} \mathrm{C}, 10 \mathrm{~min} \text { ) }\end{array}$ & 55 & 1.83 & 360 & 43.13 & 0.405 & & $P=70$ & \\
\hline ITO/AZO/ZnO/Cu ${ }_{2} \mathrm{O} / \mathrm{AgNW}$ & 80 & 2.92 & 520 & 30.62 & 0.46 & - & AM 1.5 & {$[41]$} \\
\hline $\mathrm{FTO} / \mathrm{ZnO} / \mathrm{NiO} / \mathrm{AgNW}$ & 60 & 0.728 & 749.2 & 65.71 & 0.36 & \multirow{2}{*}{$130 \times 65$} & \multirow{2}{*}{ AM 1.5} & \multirow{2}{*}{ [42] } \\
\hline $\mathrm{FTO} / \mathrm{ZnO} / \mathrm{Co}_{3} \mathrm{O}_{4} / \mathrm{NiO} / \mathrm{AgNW}$ & 30 & 2.041 & 841.8 & 77.14 & 1.33 & & & \\
\hline $\mathrm{ITO} / \mathrm{ZnO} / \mathrm{NiO} / \mathrm{AgNW}$ & \multirow{2}{*}{50} & 1.87 & 360 & 36.6 & 3.09 & \multirow{2}{*}{-} & \multirow{2}{*}{$\begin{array}{l}\lambda=365 \mathrm{~nm} \\
P=8\end{array}$} & \multirow{2}{*}[43]{} \\
\hline $\mathrm{FTO} / \mathrm{TiO}_{2} / \mathrm{ZnO} / \mathrm{NiO} / \mathrm{AgNW}$ & & 2 & 580 & 42.2 & 6.12 & & & \\
\hline \multirow{2}{*}{$\mathrm{FTO} / \mathrm{TiO}_{2} / \mathrm{SnS} / \mathrm{NiO} / \mathrm{Au}$ film } & \multirow{2}{*}{60} & 1.145 & 617 & 30 & 0.212 & \multirow{2}{*}{2500} & AM 1.5 & \multirow{2}{*}[34]{} \\
\hline & & 27.36 & 764 & 42 & 13 & & $\begin{array}{l}\lambda=365 \mathrm{~nm} \\
\quad P=60\end{array}$ & \\
\hline \multirow[t]{2}{*}{$\mathrm{FTO} / \mathrm{AZO} / \mathrm{ZnO} / \mathrm{Si} / \mathrm{NiO} / \mathrm{AgNW}$} & \multirow[t]{2}{*}{40} & 2.75 & 600 & 29.2 & 4.8 & \multirow[t]{2}{*}{144} & $\begin{array}{l}\lambda=365 \mathrm{~nm} \\
\quad P=10\end{array}$ & \multirow[t]{2}{*}[15]{} \\
\hline & & 2.70 & 598 & 34 & 0.55 & & AM 1.5 & \\
\hline
\end{tabular}

ate binding energy and thus improves the charge carrier transport. The fabricated device exhibited an improvement in the PCE from 0.065 to $0.560 \%$ owing to the introduced Si layer. These results indicate that the introduction of a wafer-scale 2D or Si layer as an absorber layer is a promising alternative technique to enhance the PCE of TPVs. The photovoltaic performance and AVT of various inorganic TPVs measured under the illumination of the AM 1.5 spectrum and light of $\lambda$ $\sim 365 \mathrm{~nm}$ are compared in Table III and Fig. 7.

Klochko et al. [35] fabricated a $\mathrm{Cu} / \mathrm{FTO} / \mathrm{ZnO} / \mathrm{NiO} / \mathrm{Cu} \mathrm{TPV}$. The $1 \mathrm{D} \mathrm{ZnO} \mathrm{nanorod} \mathrm{arrays} \mathrm{were} \mathrm{prepared} \mathrm{through} \mathrm{cathodic} \mathrm{electrochem-}$ ical deposition, and the $\mathrm{NiO}$ thin films were deposited using the successive ionic layer adsorption and reaction technique. However, the device exhibited a low photovoltaic performance, possibly because of
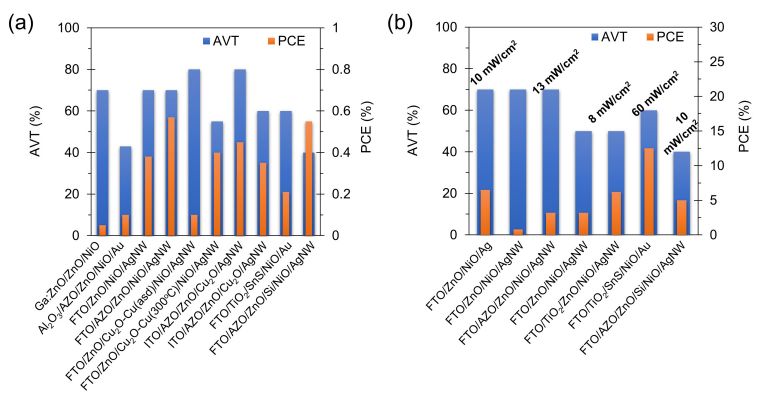

Figure 7. Graph comparing the PCE (under an AM 1.5 spectrum) and AVT values of various inorganic TPVs, measured under: (a) AM 1.5 spectrum and (b) light with $\lambda \sim 365 \mathrm{~nm}$. the high series resistance and diode ideality factor.

\section{Conclusions}

This study was performed to investigate the potential of inorganic TPVs to meet the global energy requirements with a reduced environmental impact. Inorganic TPV technology has the ability to produce cost-effective and highly stable solar cells with higher efficiency to convert the largest energy consumers, such as buildings and vehicles, into the largest energy producers. In the recent years, the semiconductor technology has been advanced with the introduction of various wide-band-gap metal oxides that have excellent optoelectrical properties and can be used in various photovoltaic applications. Among these materials, $\mathrm{NiO} / \mathrm{ZnO}$ heterojunctions with AVT and PCE values of 70.00 and $0.56 \%$, respectively, or $\mathrm{Cu}_{2} \mathrm{O} / \mathrm{ZnO}$ heterojunctions with AVT and PCE values of 80.00 and $0.46 \%$, respectively, have become the focus of inorganic TPV research. The addition of an AZO layer as the surface field layer plays a significant role in improving the photovoltaic performance of both the $\mathrm{NiO}$ - and $\mathrm{Cu}_{2} \mathrm{O}$-based TPVs. Further, the introduction of a surface field layer of $\mathrm{TiO}_{2}$ in $\mathrm{NiO} / \mathrm{ZnO}$-based TPVs yields $J_{\text {dark }} \sim 0.22 \mathrm{nA}$, whereas an AZO layer yields a $J_{\text {dark }}$ of $\sim 1-5 \mathrm{nA}$, which reveals the superiority of the $\mathrm{TiO}_{2}$ surface field layer over the AZO one. The enhanced photovoltaic performance due to the incorporation of $\mathrm{SnS}$ nanoplatelets, with a device configuration of $\mathrm{FTO} / \mathrm{TiO}_{2} / \mathrm{SnS} / \mathrm{NiO} / \mathrm{Au}$ film, as well as due to $\mathrm{Si}$, with a device configuration of $\mathrm{FTO} / \mathrm{AZO} / \mathrm{ZnO} / \mathrm{Si} / \mathrm{NiO} / \mathrm{AgNW}$, has paved a new path toward the development of cost-effective TPVs with improved efficiencies. The highest efficiency achieved to date is $0.56 \%$, with a device configuration of $\mathrm{FTO} / \mathrm{AZO} / \mathrm{ZnO} / \mathrm{NiO} / \mathrm{AgNW}$. 


\section{Acknowledgments}

This study was supported by the Basic Science Research Program through the National Research Foundation (2020R1A2C1009480 and 2020R1I1A1A01068573), funded by the Ministry of Education of Korea, Brain Pool Program funded by the Ministry of Science and ICT (NRF-2020H1D3A2A02085884), and Korea Institute of Energy Technology Evaluation and Planning (KETEP-20203030010310) of Korea

\section{Conflicts of Interest}

The authors declare no conflicts of interest.

\section{ORCID}

Benjamin Hudson Baby Malkeshkumar Patel

Kibum Lee

Joondong Kim

https://orcid.org/0000-0002-6284-4757 https://orcid.org/0000-0002-8590-0985 https://orcid.org/0000-0002-8315-9003 https://orcid.org/0000-0002-9159-0733

\section{References}

[1] Renewable Energy (accessed Jan. 6, 2022).

[2] G. Crabtree and N. Lewis, Phys. Today, 60, 37 (2007)

[3] S. Nundy, A. Mesloub, B. M. Alsolami, and A. Ghosh, J. Clean. Prod. 301, 126854 (2021).

[4] D. A. Chwieduk, Renew. Energy 101, 1194 (2017).

[5] M. Patel, J. H. Seo, T. T. Nguyen, and J. Kim, Cell Rep. Phys. Sci. 2, 100591 (2021)

[6] A. A. F. Husain, W. Z. W. Hasan, S. Shafie, M. N. Hamidon, and S. S. Pandey, Renew. Sust. Energ. Rev. 94, 779 (2018).

[7] S. Ito, P. Chen, P. Comte, M. K. Nazeeruddin, P. Liska, P. Péchy, and M. Grätzel, Prog. Photovolt. Res. Appl. 15, 603 (2007).

[8] T. T. Nguyen, M. Patel, S. Kim, V.-A. Dao, and J. Kim, ACS Appl. Mater. Interfaces 13, 10181 (2021).

[9] S. Kim, J. Yi, and J. Kim, Sol. RRL 5, 2100162 (2021).

[10] Y. Li, J.-D. Lin, X. Che, Y. Qu, F. Liu, L.-S. Liao, and S. R. Forrest, J. Am. Chem. Soc. 139, 17114 (2017).

[11] C. C. Chen et al. ACS Nano 6, 7185 (2012).

[12] C. D. Bailie et al., Energy Environ. Sci. 8, 956 (2015).

[13] J. Zhang, S. Li, P. Yang, W. Que, and W. Liu, Sci. China Mater. $58,785(2015)$

[14] A. Bahramian and D. Vashaee, Sol. Energy Mater. Sol. Cells 143, 284 (2015).

[15] S. Kim, M. Patel, T. T. Nguyen, J. Yi, C. P. Wong, and J. Kim, Nano Energy 77, 105090 (2020)

[16] M. Patel, S. Kim, T. T. Nguyen, J. Kim, and C.-P. Wong, Nano Energy 90, 106496 (2021).

[17] P. Bhatnagar, J. Hong, M. Patel, and J. Kim, Nano Energy 91, 106676 (2022).

[18] Best Research-Cell Efficiency Chart (accessed Jan. 6, 2022).

[19] F. Liu, Q. Zeng, J. Li, X. Hao, A. Ho-Baillie, J. Tang, and M. A. Green, Mater. Today 41, 120 (2020).

[20] P. Jackson, R. Wuerz, D. Hariskos, E. Lotter, W. Witte, and M. Powalla, Phys. Status Solidi - Rapid Res. Lett. 10, 583 (2016).

[21] W. Wang, M. T. Winkler, O. Gunawan, T. Gokmen, T. K. Todorov, Y. Zhu, and D. B. Mitzi, Adv. Energy Mater. 4, 1301465 (2014).

[22] Y. Lee, S. Biswas, and H. Kim, Appl. Sci. Converg. Technol. 30, 159 (2021)

[23] A. Yella et al., Science 334, 629 (2011).

[24] Q. Liu et al., Sci. Bull. 65, 272 (2020).

[25] B. Joseph, T. Pogrebnaya, and B. Kichonge, Int. J. Photoenergy 2019, 5214150 (2019).

[26] C. J. Traverse, R. Pandey, M. C. Barr, and R. R. Lunt, Nat. Energy 2, 849 (2017)

[27] W. Shockley and H. J. Queisser, J. Appl. Phys. 32, 510 (1961).
[28] C. D. Bailie et al., Energy Environ. Sci. 8, 956 (2015).

[29] K. Jo and H. J. Kim, Appl. Sci. Converg. Technol. 30, 14 (2021).

[30] M. Bidikoudi and E. Kymakis, J. Mater. Chem. C 7, 13680 (2019).

[31] J. Chen and N.-G. Park, J. Phys. Chem. C 122, 14039 (2018).

[32] S. S. Shin, S. J. Lee, and S. I. Seok, Adv. Funct. Mater. 29, 1900455 (2019).

[33] M. Patel, H. S. Kim, J. Kim, J. H. Yun, S. J. Kim, E. H. Choi, and H. H. Park, Sol. Energy Mater. Sol. Cells 170, 246 (2017).

[34] M. Patel et al., Nano Energy 68, 104328 (2020).

[35] N. P. Klochko et al., Sol. Energy 164, 149 (2018).

[36] K. Tonooka, H. Bando, and Y. Aiura, Thin Solid Films 445, 327 (2003).

[37] M. Warasawa, Y. Watanabe, J. Ishida, Y. Murata, S. F. Chichibu, and M. Sugiyama, Jpn. J. Appl. Phys. 52, 021102 (2013).

[38] R. Karsthof, P. Räcke, H. Von Wenckstern, and M. Grundmann, Phys. Status Solidi A. 213, 30 (2016).

[39] D. Ban, M. Patel, T. T. Nguyen, and J. Kim, Adv. Electron. Mater 5, 1900348 (2019).

[40] A. K. Rana, J. T. Park, J. Kim, and C.-P. Wong, Nano Energy 64 103952 (2019).

[41] A. Kumar Rana, D.-K. Ban, M. Patel, J.-H. Yun, and J. Kim Mater. Lett. 255, 126517 (2019).

[42] M. Patel, D.-K. Ban, T. T. Nguyen, and J. Kim, ECS Trans. 92, 15 (2019).

[43] T. T. Nguyen, M. Patel, J.-W. Kim, W. Lee, and J. Kim, J. Alloys Compd. 816, 152602 (2020).

[44] Q. Xue, R. Xia, C. J. Brabec, and H. L. Yip, Energy Environ. Sci. 11,1688 (2018)

[45] A. Roy, A. Ghosh, S. Bhandari, S. Sundaram, and T. K. Mallick, Buildings 10, 129 (2020).

[46] E. Pulli, E. Rozzi, and F. Bella, Energy Convers. Manag. 219, $112982(2020)$.

[47] A. S. Reddy, H.-H. Park, G. M. Rao, S. Uthanna, and P. S. Reddy, J. Alloys Compd. 474, 401 (2009).

[48] M. I. Medina-Montes, H. Arizpe-Chávez, L. A. BaldenegroPérez, M. A. Quevedo-López, and R. Ramírez-Bon, J. Electron. Mater. 41, 1962 (2012).

[49] C. Agashe, O. Kluth, J. Hüpkes, U. Zastrow, B. Rech, and M. Wuttig, J. Appl. Phys. 95, 1911 (2004).

[50] Y. Tao, B. Zhu, Y. Yang, J. Wu, and X. Shi, Mater. Chem. Phys. 250, $123129(2020)$

[51] M. A. Islam, K. S. Rahman, H. Misran, N. Asim, M. S. Hossain, M. Akhtaruzzaman, and N. Amin, Results Phys. 14, 102518 (2019).

[52] R. Prajesh, V. Goyal, M. Nahid, V. Saini, A. K. Singh, A. K. Sharma, J. Bhargava, and A. Agarwal, Sens. Actuators B Chem. 318, 128166 (2020).

[53] M. S. Jamal et al., Results Phys. 14, 102360 (2019).

[54] S. Dolai, S. Das, S. Hussain, R. Bhar, and A. K. Pal, Vacuum 141, 296 (2017).

[55] R.-S. Yu and Y.-C. Lee, Thin Solid Films 646, 143 (2018)

[56] K. Ueda, T. Hase, H. Yanagi, H. Kawazoe, H. Hosono, H. Ohta, M. Orita, and M. Hirano, J. Appl. Phys. 89, 1790 (2001).

[57] M. Ahmadi, M. Asemi, and M. Ghanaatshoar, Appl. Phys. A 124 $529(2018)$

[58] R.-S. Yu and C.-M. Wu, Appl. Surf. Sci. 282, 92 (2013).

[59] T. Zhu, Z. Deng, X. Fang, W. Dong, J. Shao, R. Tao, and S. Wang, Bull. Mater. Sci. 39, 883 (2016).

[60] H. S. Kim, M. Patel, P. Yadav, J. Kim, A. Sohn, and D. W. Kim, Appl. Phys. Lett. 109, 101902 (2016).

[61] H. Zhang, H. Wang, W. Chen, and A. K. Y. Jen, Adv. Mater. 29, 1604984 (2017)

[62] S. Jeong, S. Seo, and H. Shin, RSC Adv. 8, 27956 (2018).

[63] F. Igbari, M. Li, Y. Hu, Z.-K. Wang, and L.-S. Liao, J. Mater. Chem. A. 4, 1326 (2016)

[64] H.-M. Kim, J.-H. Youn, G.-J. Seo, and J. Jang, J. Mater. Chem. C 
1,1567 (2013).

[65] F. C. Marques and J. J. Jasieniak, Appl. Surf. Sci. 422, 504 (2017).

[66] S. S. Shin, W. S. Yang, J. H. Noh, J. H. Suk, N. J. Jeon, J. H. Park, J. S. Kim, W. M. Seong, and S. I. Seok, Nat. Commun. 6, 7410 (2015).

[67] W. Ke et al., J. Am. Chem. Soc. 137, 6730 (2015).

[68] K. O. Ukoba, A. C. Eloka-Eboka, and F. L. Inambao, Renew. Sustain. Energy Rev. 82, 2900 (2018).

[69] M. Patel and J. Kim, J. Alloys Compd. 729, 796 (2017).

[70] J. Urieta-Mora, I. García-Benito, A. Molina-Ontoria, and N. Martín, Chem. Soc. Rev. 47, 8541 (2018).

[71] P. Kung, M. Li, P. Lin, Y. Chiang, C. Chan, T. Guo, and P. Chen, Adv. Mater. Interfaces 5, 1800882 (2018).

[72] Ø. Nordseth et al., Materials 11, 2593 (2018).

[73] N. Zhang, J. Sun, and H. Gong, Coatings 9, 137 (2019).
[74] D. Reyes-Coronado, G. Rodríguez-Gattorno, M. E. EspinosaPesqueira, C. Cab, R. de Coss, and G. Oskam, Nanotechnology 19, 145605 (2008).

[75] M. Patel, S. Park, and J. Kim, Phys. Status Solidi A 215, 1800216 (2018).

[76] P. Mahala, M. Patel, D. K. Ban, T. T. Nguyen, J. Yi, and J. Kim, J. Alloys Compd. 827, 154376 (2020).

[77] T. T. Nguyen, M. Patel, and J. Kim, Surf. Interfaces 23, 100934 (2021).

[78] T. T. Nguyen, M. Patel, J. W. Kim, W. Lee, and J. Kim, J. Alloys Compd. 816, 152602 (2020).

[79] S. Kim, J. Yi, and J. Kim, Sol. RRL 5, 2100162 (2021).

[80] S. Kim, M. Patel, Y. Kim, J. Yi, and J. Kim, J. Mater. Lett. 289, 129390 (2021). 